\title{
Risk Factors Associated with Pestedes Petits Ruminants (PPR) in Sheep and Goats in Makurdi, Benue State
}

\author{
Victor $\mathbf{I}^{1 *}$ Akuve $\mathrm{B}^{1}$, Buba $\mathrm{E}^{2}$, Helen $\mathrm{AO}^{1}$ \\ ${ }^{1}$ Department of Veterinary medicine, College of Veterinary Medicine, University of Agriculture, Makurdi, Nigeria \\ ${ }^{2}$ Department of Animal Health and Production, College of Veterinary Medicine, University of Agriculture, Makurdi, Nigeria
}

"Corresponding author: Victor I, Department of Veterinary medicine, College of Veterinary Medicine, University of Agriculture, Makurdi Nigeria. E-mail: vicshallom@yahoo.com

Citation: Victor I, Akuve B, Buba E, Helen AO (2017) Risk Factors Associated with Pestedes Petits Ruminants (PPR) in Sheep and Goats in Makurdi, Benue State. Arch Vet Sci Technol: AVST: 120. DOI:10.29011/AVST-120/100020

Received Date: 5 June, 2017; Accepted Date: 10 June, 2017; Publishers Date: 17 June, 2017

\begin{abstract}
Purpose. Peste des Petits Ruminants (PPR) is a highly contagious viral disease of sheep and goats. The disease is considered to be one of the main constraints to the productivity of small ruminants in the Sub-Saharan countries including Nigeria and the globe at large. This work is aimed at assessing the risk factors associated with the prevalence of PPR in Makurdi.
\end{abstract}

Methods: In this study, the location of interest (Makurdi) was divided into four blocks using Random block sampling method, with each township area representing a block. A total of 152 questionnaires were distributed in this study to assess the association of eleven risk factors (Locality, husbandry system, housing, herd size and composition, species, breed, sex, age, climate change/season, medication/vaccination, and source of the animal) with the occurrence of PPR in small ruminant's population.

Results: Ten different factors (with $p$-value $\leq 0.05$ ) were found to be associated with PPR in Makurdi. The overall prevalence of PPR in Makurdi was found to be $51.3 \%$. The incidence of PPR was found to be very high in dry season than rainy season. Demographically, animals less than 12 months of age and mostly female animals were most affected by PPR, and goats were found to be highly susceptible to PPR than sheep.

Conclusion: The results of this study showed that PPR is an important goat and sheep disease in the studied area. Thus, an appropriate control strategy has to be designed and applied, which could involve prevention of contact with infected goats and vaccination against the PPR virus.

Keywords: PPR; Risk Factors; Ruminants

\section{Introduction}

Peste des petits ruminants (PPR) is a highly contagious viral disease of sheep and goats [1]. Morbidity and mortality vary considerably and can be as high as 90 to $100 \%$ depending on the susceptibility of the small ruminants' population in an area, animal husbandry, breed and age [2]. Clinically, the disease is characterized by severe pyrexia, catarrhal ocular and mucopurulent nasal discharges, erosive stomatitis in early stages followed by severe enteritis and pneumonia.

Peste des Petits Ruminants (PPR) is considered a disease of great economic impact as reported by the World Animal Health Organization (OIE) particularly in the inter-tropical regions of Af- rica, in the Arabian Peninnsula, the Middle East and Asia [3,4]. PPR is currently considered to be one of the main animal transboundary diseases that constitute a significant threat to small ruminant production in developing countries

In Nigeria, the disease was first described under such names as "Kata" (catarrh) by [5]; Pseudo-rinderpest [6] and Stomatitis Pneumoenteritis Complex [7]. It was Subsequently reported by [8]. There are no known health risks to humans working with PPRV as no report of human infection with the virus exists [9]. A look into the factors that potentiate the disease among small ruminant's population is critical in understanding epidemiology and control of the disease. The aim of the study is to determine and assess the possible conditions (risk factors) that promote high incidence of the disease in a susceptible population of sheep and goats in 


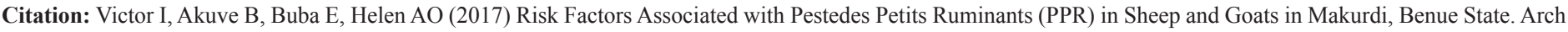
Vet Sci Technol: AVST: 120.

Makurdi. Secondly, to determine the impact of PPR and the most appropriate socio-economically sound approaches to PPR prevention and control in Makurdi.

\section{Materials and Method}

\section{Study Area}

The study was conducted in four township areas of Makurdi Local Government Area (Longitude $8.5^{\circ} \mathrm{E}$ and Latitude $7.74^{\circ}$ North) of Benue State designated as blocks. They include: North-Bank (in the North), Wurukum (in the Central area), Wadata (in the South) and Modern Market/Ankpa Ward (in the west). The annual rainfall is between $1200-1500 \mathrm{~mm}$ and mean temperature of $21^{\circ} \mathrm{C}-30{ }^{\circ} \mathrm{C}$ [10]

\section{Sampling and Data Collection}

Using Random block sampling method, the study area (Makurdi) was divided into four blocks with each township area representing a block. A total of 152 questionnaires were distributed to farmers and herds men for risk factor assessment and a total of 11 risk factors were assessed to determine their association with the occurrence of PPR in sheep and goat in Makurdi. Fifty (50) questionnaires were administered in North-Bank, thirty (30) in Wurukum, thirty-three (33) in Wadata and thirty-nine (39) in Modern-Market/Ankpa Ward. The eleven risk factors assessed include: Locality, husbandry system, housing, herd size and composition, species, breed, sex, age, climate change/season, medication/ vaccination, and source of the animal.

\section{Data Analysis}

Data obtained were analyzed using Graph Pad Prism computer software version 5.0 in a 2-tailed Chi-square test to determine the association between the investigated 11 risk factors and PPR positive and negative cases as suggested from the information provided by the farmers and herd owners in the questionnaire (univariate analysis). A logistic regression model was then used to assess the association between the risk factors (with $\mathrm{p} \leq 0.05$ ) and the PPR positive and negative cases (multivariate analysis).

\section{Result and Discussion}

\section{Univariate analysis using Chi-square}

Eleven risk factors were assessed using a structured questionnaire for every sampled herd. Ten different factors (with pvalue $\leq 0.05$ ) were found to be associated with PPR as shown in (Table 1).

\begin{tabular}{|c|c|c|c|c|c|c|c|}
\hline Risk factor & & $\begin{array}{c}\text { No of tested } \\
\text { animals }\end{array}$ & $\begin{array}{c}\text { No of positive } \\
\text { samples }\end{array}$ & Prevalence $(\%)$ & $\mathrm{X}^{2}$ & df & p-value \\
\hline \multirow{4}{*}{ Locality } & $\mathrm{A}$ & 50 & 32 & 64 & 8.732 & 3 & 0.0331 \\
\hline & B & 30 & 18 & 60 & & & \\
\hline & $\mathrm{C}$ & 33 & 12 & 36.4 & & & \\
\hline & $\mathrm{D}$ & 39 & 16 & 41 & & & \\
\hline \multirow{4}{*}{$\begin{array}{l}\text { Husbandry } \\
\text { system }\end{array}$} & A & 32 & 23 & 72 & 2.437 & 3 & 0.0001 \\
\hline & $\mathrm{B}$ & 22 & 14 & 63.6 & & & \\
\hline & $\mathrm{C}$ & 38 & 6 & 15.7 & & & \\
\hline & $\mathrm{D}$ & 60 & 35 & 58.3 & & & \\
\hline \multirow{6}{*}{ Housing } & A & 54 & 38 & 70.4 & 13.68 & 5 & 0.0178 \\
\hline & $\mathrm{B}$ & 43 & 12 & 27.9 & & & \\
\hline & $\mathrm{C}$ & 5 & 1 & 20 & & & \\
\hline & $\mathrm{D}$ & 12 & 7 & 58.3 & & & \\
\hline & $\mathrm{E}$ & 21 & 11 & 22.4 & & & \\
\hline & $\mathrm{F}$ & 17 & 9 & 52.9 & & & \\
\hline \multirow{3}{*}{$\begin{array}{l}\text { Herd composi- } \\
\text { tion }\end{array}$} & $\mathrm{A}$ & 43 & 19 & 44.2 & 1.623 & 2 & $0.4442 *$ \\
\hline & $\mathrm{B}$ & 17 & 8 & 47.1 & & & \\
\hline & $\mathrm{C}$ & 92 & 51 & 55.4 & & & \\
\hline \multirow{2}{*}{ Species } & A & 37 & 13 & 35.1 & 5.125 & 1 & 0.0236 \\
\hline & $\mathrm{B}$ & 115 & 65 & 56.5 & & & \\
\hline
\end{tabular}




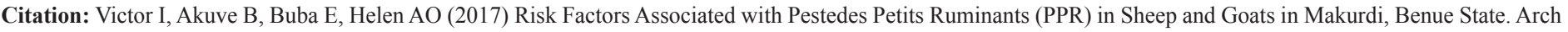
Vet Sci Technol: AVST: 120.

\begin{tabular}{|c|c|c|c|c|c|c|c|}
\hline \multirow{4}{*}{$\begin{array}{c}\text { Vaccination } \\
\text { status }\end{array}$} & A & 15 & 3 & 20 & 34.86 & 3 & 0.0001 \\
\hline & B & 23 & 3 & 13 & & & \\
\hline & $\mathrm{C}$ & 39 & 17 & 43.6 & & & \\
\hline & $\mathrm{D}$ & 75 & 55 & 73.3 & & & \\
\hline \multirow{3}{*}{$\begin{array}{l}\text { Source of } \\
\text { animal }\end{array}$} & $\mathrm{A}$ & 74 & 51 & 68.9 & 27.99 & 2 & 0.001 \\
\hline & B & 53 & 19 & 45.9 & & & \\
\hline & $\mathrm{C}$ & 25 & 8 & 32 & & & \\
\hline \multirow{3}{*}{ Breed (Goats) } & A & 66 & 46 & 69.7 & 8.010 & 2 & 0.0182 \\
\hline & B & 40 & 27 & 67.5 & & & \\
\hline & $\mathrm{C}$ & 9 & 2 & 22.2 & & & \\
\hline \multirow{2}{*}{ Breed (Sheep) } & A & 24 & 13 & 29.2 & 5.261 & 1 & 0.0218 \\
\hline & B & 13 & 2 & 30.8 & & & \\
\hline \multirow{2}{*}{ Sex } & A & 61 & 33 & 54.1 & 6.969 & 1 & 0.0083 \\
\hline & B & 91 & 68 & 74.7 & & & \\
\hline \multirow{3}{*}{ Age } & A & 33 & 9 & 27.3 & 10.15 & 2 & 0.0062 \\
\hline & $\mathrm{B}$ & 39 & 21 & 53.8 & & & \\
\hline & $\mathrm{C}$ & 80 & 48 & 60 & & & \\
\hline \multirow{2}{*}{ Season/Climate } & A & 63 & 21 & 33.3 & 13.93 & 1 & 0.0002 \\
\hline & B & 89 & 57 & 64.1 & & & \\
\hline
\end{tabular}

Table 1: Prevalence/Incidence rates of PPR in North-Bank, Wurukum, Wadata and Modern Market/Ankpa Ward areas of Makurdi and the number of animals investigated.

\section{Multivariate analysis using Logistic regression}

The risk factors, suspected to be associated with PPR from univariate analysis, were further subjected to multivariate analysis using Logistic Regression model as shown in (Table 2).

\begin{tabular}{|c|c|c|c|c|c|}
\hline $\begin{array}{c}\text { No of questionnaires for +ve } \\
\text { PPR Incidence }\end{array}$ & 32 & 18 & 12 & 16 & 78 \\
\hline Prevalence/Incidence (\%) & 64 & 60 & 36.36 & 41.03 & \\
\hline No of Sheep & 14 & 6 & 8 & 9 & 37 \\
\hline No of Goats & 36 & 24 & 25 & 30 & 115 \\
\hline Males & 24 & 9 & 13 & 15 & 61 \\
\hline Females & 26 & 21 & 20 & 24 & 91 \\
\hline $\begin{array}{c}\text { Adults } \\
\text { Kids and Lambs }\end{array}$ & 29 & 17 & 18 & 16 & 80 \\
\hline & 21 & 13 & 15 & 23 & 72 \\
\hline
\end{tabular}

Table 2: Univariate analysis for risk factor associated with PPR prevalence using Chi-square $(\chi 2)$ test.

Furthermore, Summary percentage distribution of PPR prevalence based on localities in Makurdi is presented in (Table 3).

\begin{tabular}{|c|c|c|c|}
\hline Location & No of samples & No positive & $\begin{array}{c}\text { Percentage } \\
\text { Prevalence }\end{array}$ \\
\hline North-Bank & 50 & 32 & 41.0 \\
\hline Wurukum & 30 & 18 & 23.1 \\
\hline Wadata & 33 & 12 & 15.4 \\
\hline $\begin{array}{c}\text { Modern } \\
\text { Market/Ankpa } \\
\text { Ward }\end{array}$ & 39 & 16 & 20.5 \\
\hline Total & 152 & 78 & 100 \\
\hline
\end{tabular}

Table 3: Percentage distribution of PPR prevalence in Makurdi by location.

Assessment of risk factors is important for effective control and eradication of PPR in this study, the overall prevalence of PPR in Makurdi was found to be $51.3 \%$. From all the locations, NorthBank was found to have the highest PPR prevalence in Makurdi with prevalence rate of $64 \%$. This may be attributed to the high small ruminant population in North-Bank area as the International Cattle Market which also serves as a goat and sheep market (where the major large and small ruminant transactions in Makurdi takes place) is situated there. Wurukum, Wadata and Modern Market 


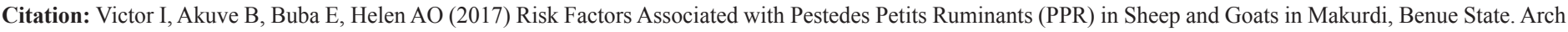
Vet Sci Technol: AVST: 120.

areas had prevalence rates of $60 \%, 36.5 \%$ and $41 \%$ respectively. This study showed that the overall prevalence $(51.3 \%)$ was low as compared to some other previous studies; for example, 54\% by [11], $61.8 \%$ by [12], $62.8 \%$ by [13], and $70.2 \%$ by [14]. This variation might be due to the wide-coverage of vaccination against PPR in 2010 and 2011 (Mai, et al. 2004). These findings agreed with the reports of [15].

In this study, animals reared under open grazing and pastoralist systems had higher prevalence, with prevalence rates of $71.2 \%$ and $63.6 \%$ respectively. Low prevalence was found in the animals reared in intensive and semi-intensive systems $(15 \%$ and $58 \%$ ). This was similar to the findings of [14]. In addition, this could also be attributed to the restricted movements of the animals kept under the latter systems as well as to the vulnerability of small ruminant herds in pastoralist and open grazing systems to infected herds in pastures and water points. This finding is in agreement with the observations of [15]. PPR prevalence was found to differ significantly between housing categories. Among the animal housing types, the animals without housing had the highest PPR prevalence $(70.4 \%)$ followed by animals in barbed wire/wire mesh, shrub and scrap fences with prevalence rates of $52.9 \%, 58.3 \%$ and $52.4 \%$. The prevalence rate in animals kept in modern houses with fences was found to be low. Animals kept in mud and brick houses had the lowest prevalence rates of $27.9 \%$ and $20 \%$ respectively as shown in (Table 2).

Furthermore, Females were more affected with PPR, with a prevalence rate of $74.7 \%$ than males $(54.1 \%)$ thereby agreeing with [12]. The present breeding system in Makurdi could be the reason for this variation as female animals were kept longer time for reproduction purpose. But, it disagreed with [16] who stated that males are most affected by PPR, and this might be due to genetic variation of the animals. Animals older than 12 months of age had the highest prevalence $(60 \%)$ followed by animals from 4 to 12 months of age as shown in (Table 2). This can be attributed to waning of the maternal immunity in young animals older than 4 months of age and the absence of PPR antibodies in the serum of older animals never exposed to or vaccinated against the disease. Low prevalence was found in kids and lambs ageing 1 to 3 months. This can be attributed to the presence of maternal colustral antibodies. These results agree with the findings of [17], who reported a higher prevalence in animals older than 2 years. In this study, goats were found to have higher prevalence $(56.5 \%)$ than sheep (35.1\%), this finding is consistent with the report of [1].

The West African Dwarf (WAD) breed of goat was found to have higher PPR prevalence (69.7\%) than the Sokoto red (67.5\%) and Sahel $(22.2 \%)$ breeds of goat. Similarly, the Yankasa breed of sheep was found to have a higher prevalence $(30.8 \%)$ than the West African Dwarf (WAD) breed sheep (29.2\%). These may be due to genetic factors. Prevalence of PPR in Makurdi is higher during the dry/harmattan season $(64.1 \%)$ than in the wet/rainy season
$(33.3 \%)$. These findings agree with the report of while it differed from the findings of $[12,14]$. Seasons with high wind-speed significantly supports aerosol transmission of PPR compared to the season with slow wind-speed. Animals vaccinated and on medication history have lower rate of PPR (73.3\%) compare to those with no vaccination history but have some medication history (43.6\%). In this study, animals obtained from open market showed higher prevalence rate $(68.9 \%)$ than those obtained from farm owners via breeding and as gifts (35.9\% and 32\% respectively). This may be due to; most animals sourced from the open market are sick animals that owners want to sale to minimize loss or animals that have contracted the disease via co-mingling with sick animals in the market/sales point prior to being bought as the disease is transmitted via close contact with infected animal's secretions and excretions of infected animals [3].

\section{Conflict of Interests}

The authors of this article declare that there is no conflict of interest regarding the publication of this paper.

\section{References}

1. Couacy-Hymann E, Roger F, Hurard C, Guilou JP, Libeau G, et al. (2002) Rapid and sensitive detection of PPRV by a PCR assay. Journal of Virology Methods 100: 17-25.

2. Ezeokoli CD, Umoh JU, Chineme CN, Isitor GN, And EO, et al. (1986) Clinical and epidemiological features of Peste des Petits ruminants in Sokoto Red goats. Rev Elev.Med.Vet Pays Trop 39: 269-273.

3. Abu Elzein EM, Hassanien MM, Al-Afaleq Al, Abd Elhadi MA, Housawi FM (1990) Isolation of peste des petits ruminants from goats in Saudi Arabia. Veterinary Record 127: 309-310.

4. Diallo G, Libeau E, Couacy-Hymann, Barbron M (1995) Recent developments in the diagnosis of rinderpest and peste des petits ruminants. Veterinary Microbiol 44: 307-317.

5. Whitney JC, Scott GR, Hill DH (1967) Preliminary observations on a stomatitis and enteritis of goats in Southern Nigeria. Bulletin of Epizootic Diseases Africa 15: 31-41.

6. Durtnell R, Eid FIA (1973) Preliminary note on a disease resembling Peste des Petits Ruminants in Sokoto province, North-Western State, Nigeria. Nigerian Veterinary Journal 2: 8-21.

7. Forsyth MA, Barrett T (1995) Evaluation of polymerase chain reaction for the detection and characterization of rinderpest and peste des petits ruminant's viruses for epidemiological studies. Virus Resource 39: 151-63.

8. Singh RP, De UK, Pandey KD (1995) Virological and antigenic characterization of two peste des petits ruminants (PPR) vaccine viruses of Indian origin. Comp Immunol Microbiol Infect Dis 33: 343-353.

9. Nduaka O, Ihemelandu EC (1973) Observations on pneumonia-enteritis complex in dwarf goats in Eastern Region of Nigerian-Preliminary report. Bulletin of Epizootic Diseases of Africa 21: 89-98.

10. Amadi SO, Udo SO, Ewona IO (2014) Trends and variations of monthly mean minimum and maximum temperature data over Nigeria for the period 1950-2012. International Journal of Pure and Applied phisics 4: $1-27$. 
Citation: Victor I, Akuve B, Buba E, Helen AO (2017) Risk Factors Associated with Pestedes Petits Ruminants (PPR) in Sheep and Goats in Makurdi, Benue State. Arch Vet Sci Technol: AVST: 120.

11. Haroun M, Hajer I, Mukhtar M, Ali BE (2002) Detection of antibodies against Peste des petits ruminants in sera of cattle, camels, sheep and goats in Sudan. Veterinary Research Communications 26: 537-541.

12. Abdalla AS, Majok AA, Elmalik KH, Ali AS (2012) Sero-prevalence of Peste des Petits ruminant's virus (PPRV) in small ruminants in Blue Nile, Gadaref and North Kordofan States of Sudan. Journal of Public Health and Epidemiology 4: 59-64.

13. Saeed IK, Khalfalla AI, EIHassan SM, EIAmin MA (2004) PPR in the Sudan: investigation of recent outbreaks, virus isolation and cell culture spectrum. Journal of Animal and Veterinary Advances 3: 361- 365

14. Kihu SM, Gitau CG, Bebora LC, Njenga MJ, Wairire GG (2010) Risk factors associated with spread ofPPR in Turkana district, kenya, Third forum meeting Entebbe, Uganda. Research Application summary 529-535.
15. Saeed IK, Ali YH, Khalfalla AI, Rahman-Mahasin EA (2010) Current situation of Peste des petits ruminants (PPR) in the Sudan. Tropical Animal Health and Production 42: 89-93.

16. Sarker S, Islam H (2011) Prevalence and risk factors assessment of PPR in goats in Rajshahi, Bangladesh. Veterinary World 4: 546-549.

17. Abubakar M, Jamal SM, Arshad MJ, Hussain M, Ali Q (2009) Peste des petits ruminant's virus (PPRV) infection; its association with species, seasonal variations and geography. Tropical Animal Health and Production 41: 1197-1202. 